\title{
The Construction of Early-warning Index System in Regional Circular Economy of China
}

\author{
Yanqing Kang ${ }^{1, *}$ and Rui Zhang ${ }^{2}$ \\ ${ }^{1}$ College of Administrative Engineering, Zhengzhou University, Zhengzhou, 450001, China \\ ${ }^{2}$ College of Management and Economics, Tianjin University, Tianjin, 300072, China \\ Corresponding E-mail: kang4006@126.com
}

\begin{abstract}
In this paper, the model of early warning system for circular economy development system was studied, the early-warning system for circular economy provides a quantitative model to support the pollution control. Specifically, this paper built an early warning index system of regional circular economy, and put forward the measure model for the development of circular economy. In addition, this paper constructed prediction model of the circulation economy development. Finally, by the proposed early warning model, this paper analysed the circular economy of Henan province and targeted policy suggestions were put forward for the construction of circular economy of Henan province.
\end{abstract}

\section{Introduction}

Circular economy is a thought of sustainable development and thought the ecology rule to realize the recycling of resources. It is taken the resources as highly efficient and recycling materials, with low consumption, high efficiency and low emissions as a basic feature of economic growth mode. In addition, circular economy pursues the maximum of using energy and recourses and the minimum of discharge of wastes, doing like this is in order to build the chronic circular development.

At present, the theory and operating mechanism of circular economy system have become increasingly attention and the quantitative researches are mainly through the construction of index system to measure the circular economy development level, Such as Zhang [1], Yang [2], Ouyang [3], Zhao [4], Xiang [5], mostly considered "3R" principle as the starting point, through investigating the circulation economy connotation and development model to building can measure the index system of circular economy for the corresponding research. Specific to regional research, Zhong [6], Cao [7], Huang and Ping [8] discussed the development phase and mode of regional circular economy to build the corresponding index system and give a comprehensive evaluation of the development level of regional circular economy in the paper.

Resent some years, through building scientific index system then according to the index system of regional circular economy to predict the future development trend gradually becomes important, literature such as Tong [9], Qin [10] and Qian [11] has studied the construction of early warning system for regional circular economy, but the methods are different. On the basis of these articles, this paper will evaluate the development level of regional circular economy and gives corresponding judgment and warning about future development through the establishment of the corresponding early warning index system of Henan province.

The rest of this article is presented as follows. Firstly, this paper conducts the construction of regional index system and introduces the weight given by the method in section 2. Secondly, section 3 introduces and processes the data. Thirdly, this paper builds the early warning system through the index system and analyses the development level of circular economy of Henan province in section 4. Finally, section 5 summarizes the conclusions and puts forward suggestions.

\section{The index system and weight method}

\subsection{The conduction of index system}

This paper discusses the necessity of constructing an index system of regional sustainable development and basic principles while constructing the system. Index system must be able to compare the construction of a comprehensive response to a development level of regional circular economy, but also need to consider on index selection of 
independent and representative principle, this article refers to various research literature on the basis of fully, constructs in the following evaluation index system of regional circular economy in Table 1.

Table 1. The index system of circular economy.

\begin{tabular}{|c|c|c|}
\hline \multicolumn{2}{|l|}{ Index layer } & \multirow{2}{*}{\begin{tabular}{|c} 
characters of index \\
positive
\end{tabular}} \\
\hline Per capita GDP (yuan/person) & $\mathrm{X} 1$ & \\
\hline The third industry of GDP $(\%)$ & $\mathrm{X} 2$ & positive \\
\hline Disposable income of urban residents & $\mathrm{X} 3$ & positive \\
\hline Per capita net income of farmers & $\mathrm{X} 4$ & positive \\
\hline High technology production value of industrial output value $(\%)$ & $\mathrm{X} 5$ & positive \\
\hline $\mathrm{R} \& \mathrm{D}$ share of GDP $(\%)$ & X6 & positive \\
\hline Environmental pollution control investment of GDP (\%) & $\mathrm{X} 7$ & positive \\
\hline The standard discharge rate of industrial wastewater(\%) & $\mathrm{X} 8$ & positive \\
\hline Industrial dust removal rate $(\%)$ & $\mathrm{X} 9$ & positive \\
\hline The standard discharge rate of industrial $\mathrm{SO}_{2}$ emissions $(\%)$ & $\mathrm{X} 10$ & positive \\
\hline The standard discharge rate of industrial soot emissions (\%) & $\mathrm{X} 11$ & positive \\
\hline The repetitive use rate of industrial water $(\%)$ & $\mathrm{X} 12$ & positive \\
\hline The treatment rate of urban wastewater $(\%)$ & $\mathrm{X} 13$ & positive \\
\hline The comprehensive utilization rate of industrial solid waste $(\%)$ & $\mathrm{X} 14$ & positive \\
\hline "Three wastes" comprehensive utilization rate of gross industrial output value (\%) & $\mathrm{X} 15$ & positive \\
\hline Elasticity coefficient of energy consumption & $\mathrm{X} 16$ & negative \\
\hline Fertilizer usage per hectare $(\mathrm{kg})$ & $\mathrm{X} 17$ & negative \\
\hline Pesticides usage per hectare $(\mathrm{kg})$ & $\mathrm{X} 18$ & negative \\
\hline Energy consumption (tce/ten thousand yuan) & $\mathrm{X} 19$ & negative \\
\hline Power consumption (KWH/ten thousand yuan) & $\mathrm{X} 20$ & negative \\
\hline Energy consumption per unit value added of industry (tce/ten thousand yuan) & $\mathrm{X} 21$ & negative \\
\hline water consumption $\left(\mathrm{m}^{3} /\right.$ ten thousand yuan) & $\mathrm{X} 22$ & negative \\
\hline $\mathrm{SO}_{2}$ emissions intensity $\left(\mathrm{m}^{3} /\right.$ ten thousand yuan $)$ & $\mathrm{X} 23$ & negative \\
\hline COD emissions intensity ( $\mathrm{kg} /$ ten thousand yuan $)$ & $\mathrm{X} 24$ & negative \\
\hline Urban residents engel's coefficient $(\%)$ & $\mathrm{X} 25$ & negative \\
\hline Built-up area green coverage rate $(\%)$ & $\mathrm{X} 26$ & positive \\
\hline Per capita green area of park $\left(\mathrm{m}^{2}\right)$ & $\mathrm{X} 27$ & positive \\
\hline Hazard-free treatment rate of urban living garbage $(\%)$ & $\mathrm{X} 28$ & positive \\
\hline Spending on education career of GDP (\%) & X29 & positive \\
\hline Registered urban unemployment rate (\%) & X30 & negative \\
\hline Per capita area of urban road $\left(\mathrm{m}^{2}\right)$ & X31 & positive \\
\hline
\end{tabular}

\subsection{The weight method}

Considering weight coefficient of index belong to different hierarchy should measure the overall index under the degree of influencing on other indicators. The thought of variance drive exactly conforms to the basic ideas, empowerments of the original information directly from the indexes provide the amount of information, and thus to determine the weight coefficient of each index. The specific method is introduced as follows.

Suppose there are $\mathrm{m}$ evaluation objects $\mathrm{x}_{1}, \mathrm{x}_{2}, \ldots, \mathrm{x}_{\mathrm{m}}$, corresponding weight coefficient of $\mathrm{w}_{1}, \mathrm{w}_{2}, \ldots$, and $\mathrm{w}_{\mathrm{m}}$. Use $\mathrm{x}_{\mathrm{i} 1}$, $\mathrm{x}_{\mathrm{i} 2}, \ldots, \mathrm{X}_{\mathrm{in}}$ express the ith value of each evaluation index, $\mathrm{X}=\left\{\mathrm{x}_{\mathrm{i}, \mathrm{j}}\right\}_{\mathrm{m}^{*} \mathrm{n}}$. Comprehensive evaluation function is expressed as:

$$
y_{i}=w_{1} x_{i, 1}+w_{2} x_{i, 2}+\ldots+w_{m} x_{i, m}
$$

Here 


$$
y=\left(y_{1}, y_{2}, \ldots, y_{n}\right)^{T}, w=\left(w_{1}, w_{2}, \ldots, w_{m}\right)^{T}
$$

When the original data are standardized, $y=0\left({ }^{y}\right.$ is the average of $\left.\mathrm{y}\right)$, there are

$$
\begin{gathered}
n s^{2}=y^{T} y=w^{T} X^{T} X w=w^{T} H w \\
s^{2}=\frac{1}{n} \sum_{i=1}^{n}\left(y_{i}-\bar{y}\right)^{2}=\frac{y^{T} y}{n}-\bar{y}^{2}
\end{gathered}
$$

Where $H=X^{T} X$.

The maximum value of Equation (3) will be able to get the biggest information differences between various indicators, so as to realize different drivers. Through calculating the largest eigenvalue of $\mathrm{H}$ and the corresponding eigenvectors and normalizing all the characteristics of the object vector, it can get the corresponding weighting system structure (w), then take it to Equation (1) to get the ith a comprehensive evaluation value $\left(\mathrm{y}_{\mathrm{i}}\right)$ of the object.

\subsection{The division precinct}

\begin{tabular}{|c|c|c|c|c|c|}
\hline Range & $(0.8,1]$ & $(0.6,0.8]$ & $(0.4,0.6]$ & $(0.2,0.4]$ & {$[0,0.2]$} \\
\hline Warning & non & light & intermediate & heavy & giant \\
\hline degree & police & police & police & police & police \\
\hline
\end{tabular}

This paper shows the classification standard of early warning system for circular economy in Table 2 .

Table 2. Classification standard of early warning system.

\section{The data}

The data of this paper are from Henan statistical yearbook, Henan statistical bulletin, China statistical yearbook of science and technology, China statistical yearbook, China's environmental statistics yearbook. Besides, the data are conducted by dimension.

\section{Early warning system for circular economy of Henan province}

The rest of this article will study the construction of early warning system of regional circular economy, taking Henan province as an example. This paper will make the comprehensive analysis about the development stage of circular economy in Henan, then this paper will study the development level of circular economy in Henan using the index system, and then do early-warning analysis of Henan circular economic sustainability.

\subsection{The evaluation of Henan circular economy}

According to the approach of variance drive, given the corresponding weights, the comprehensive calculation of comprehensive evaluation of Henan circular economy presented in Table 3.

Table 3 shows that circulation economy of Henan maintain has a stable development from 2005-2013. The development degree of circular economy gradual increases from 0.1990 to 0.9013 , the level of economic development rises from 0.0840 to 0.1672 , the level of green development increases from 0.0839 to 0.4826 , the level of social development rises from 0.0311 to 0.2248 . These show that the development of Henan's circular economy is growing steadily.

Table 3. Comprehensive evaluation of circular economy in Henan.

\begin{tabular}{|c|c|c|c|c|c|c|c|c|c|}
\hline & 2005 & 2006 & 2007 & 2008 & 2009 & 2010 & 2011 & 2012 & 2013 \\
\hline Level of economic development & 0.0840 & 0.1142 & 0.1285 & 0.0802 & 0.0903 & 0.0842 & 0.1477 & 0.1586 & 0.1672 \\
\hline Level of green development & 0.0839 & 0.1654 & 0.2351 & 0.3465 & 0.3945 & 0.4363 & 0.4533 & 0.4725 & 0.4826 \\
\hline Level of social development & 0.0311 & 0.0567 & 0.1276 & 0.0967 & 0.1273 & 0.1755 & 0.1991 & 0.2136 & 0.2248 \\
\hline $\begin{array}{c}\text { Development degree of circular } \\
\text { economy }\end{array}$ & 0.1990 & 0.3363 & 0.4912 & 0.5234 & 0.6121 & 0.6961 & 0.8001 & 0.8542 & 0.9063 \\
\hline
\end{tabular}


Considering the green index is the core of development level of the circular economy, this paper also carries on the further subdivided to green development index study, the results are shown in Figure 1.

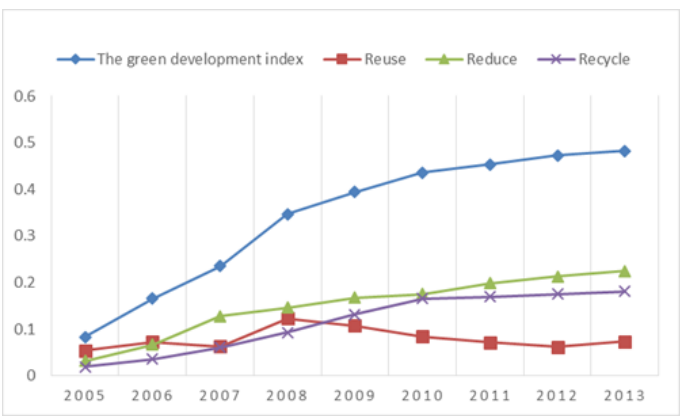

Fig. 1. Trend chart of green development index of Henan province.

Figure 1 shows that recycling and reduction index of Henan province belong to a steady rise trend in 2005-2013, but the reusing index presents a rising trend first, then showed a gradual decline trend after 2008 years. These show that there is no sustainable road in the resource utilization of Henan province.

\subsection{The construction of early warning system for Henan's circular economy}

Before undergoing early warning system for the construction of circular economy, this paper first determines the target value of various indicators and the determination of the target value need to consider the data authority, accessibility, as far as possible in accordance with the principle of circular economy. In this paper, the target values of various indicators use the value in the Henan's twelfth five-year plan for national economic and social development and the Henan's fiveyear plan of environmental protection planning as early warning target. If there are no specific targets in this papers, this paper will consider a certain index that does not affect the validity of the evaluation results. Specific results see Table 4.

Table 4. The target value of early warning index.

\begin{tabular}{|c|c|c|c|c|}
\hline Index & $\begin{array}{c}\text { Expre- } \\
\text { ssion }\end{array}$ & $\begin{array}{c}\text { Characte-rs of the } \\
\text { index }\end{array}$ & Weight & $\begin{array}{c}\text { Target } \\
\text { value }\end{array}$ \\
\hline Per capita GDP (yuan/person) & $\mathrm{X} 1$ & positive & 0.0284 & 38000 \\
\hline The third industry of GDP (\%) & $\mathrm{X} 2$ & positive & 0.0409 & 46.8 \\
\hline Disposable income of urban residents & $\mathrm{X} 3$ & positive & 0.0295 & 24460 \\
\hline Per capita net income of farmers & $\mathrm{X} 4$ & positive & 0.0277 & 8460 \\
\hline R\&D share of GDP(\%) & $\mathrm{X} 5$ & positive & 0.0265 & 7 \\
\hline High technology production value of industrial output value (\%) & $\mathrm{X} 6$ & positive & 0.0305 & 1.6 \\
\hline Environmental pollution control investment of GDP (\%) & $\mathrm{X} 7$ & positive & 0.030 & 1.39 \\
\hline The standard discharge rate of industrial wastewater(\%) & $\mathrm{X} 8$ & negative & 0.0282 & 95.3 \\
\hline Industrial dust removal rate(\%) & $\mathrm{X} 9$ & negative & 0.0373 & 92.35 \\
\hline The standard discharge rate of industrial SO ${ }_{2}$ emissions (\%) & $\mathrm{X} 10$ & negative & 0.0362 & 99.74 \\
\hline The standard discharge rate of industrial soot emissions (\%) & $\mathrm{X} 11$ & negative & 0.0331 & 97.3 \\
\hline The repetitive use rate of industrial water (\%) & $\mathrm{X} 12$ & negative & 0.0284 & 93.5 \\
\hline The treatment rate of urban wastewater (\%) & $\mathrm{X} 13$ & positive & 0.035 & 85 \\
\hline The comprehensive utilization rate of industrial solid waste (\%) & $\mathrm{X} 14$ & positive & 0.0507 & 72 \\
\hline "Three wastes" comprehensive utilization rate of gross industrial & $\mathrm{X} 19$ & negative & 0.0279 & 0.937 \\
\hline output value (\%) & $\mathrm{X} 20$ & negative & 0.0301 & 721.53 \\
\hline Elasticity coefficient of energy consumption & $\mathrm{X} 21$ & negative & 0.0293 & 1.837 \\
\hline Fertilizer usage per hectare (kg) & $\mathrm{X} 22$ & negative & 0.0366 & 1.1455 \\
\hline Pesticides usage per hectare (kg) & $\mathrm{X} 23$ & negative & 0.04 & 3.17 \\
\hline Energy consumption (tce/ten thousand yuan) & $\mathrm{X} 24$ & negative & 0.0338 & 3.4 \\
\hline Power consumption (KWH/ten thousand yuan) & & \\
\hline
\end{tabular}




\begin{tabular}{|c|c|c|c|c|}
\hline $\begin{array}{c}\text { Energy consumption per unit value added of industry (tce/ten } \\
\text { thousand yuan) }\end{array}$ & $\mathrm{X} 25$ & negative & 0.0355 & 36.3 \\
\hline water consumption $\left(\mathrm{m}^{3} /\right.$ ten thousand yuan) & $\mathrm{X} 26$ & positive & 0.036 & 45 \\
\hline $\mathrm{SO}_{2}$ emissions intensity $\left(\mathrm{m}^{3} /\right.$ ten thousand yuan) & $\mathrm{X} 27$ & positive & 0.0285 & 12 \\
\hline $\mathrm{COD}$ emissions intensity $(\mathrm{kg} /$ ten thousand yuan) & $\mathrm{X} 28$ & positive & 0.0245 & 80 \\
\hline Urban residents engel's coefficient $(\%)$ & $\mathrm{X} 29$ & positive & 0.0363 & 4 \\
\hline Built-up area green coverage rate $(\%)$ & $\mathrm{X} 30$ & negative & 0.0296 & 3.38 \\
\hline Per capita green area of park $\left(\mathrm{m}^{2}\right)$ & $\mathrm{X} 31$ & positive & 0.0284 & 13.8 \\
\hline
\end{tabular}

We conduct the standardization of every index. Then use the calculation of early warning index of the development of Henan's circular economy to make a comprehensive index. The warning degree classification of early-warning of Henan's circular economy are shown in Table 5.

Table 5. The early warning of Henan's circular economy from 2005-2013.

\begin{tabular}{|c|c|c|c|c|c|}
\hline Year & 2005 & 2006 & 2007 & 2008 & 2009 \\
\hline Warning degree & 0.0625 & 0.1724 & 0.3357 & 0.4534 & 0.5025 \\
\hline Year & 2010 & 2011 & 2012 & 2013 & \\
\hline Warning degree & 0.6134 & 0.7241 & 0.7725 & 0.8316 & \\
\hline
\end{tabular}

It can be seen from Table 5 that the warning degree of early warning system for Henan's circular economy in 2005 and 2006 are giant police, heavy police in 2007, intermediate police in 2008 and 2009, and light police from 2010 to 2013. The development level of Henan's circular economy shows a better trend in the whole. Considering that Henan pays attention to circular economy, takes sustainable development road, and doesn't increase outputs are at the expense of resources and environment. Hence, it is imperial to attach importance to environmental protection in developing recycling economy and promoting new-type development road.

\section{Conclusion}

This paper built an early-warning index system of regional circular economy, and put forward the measure model for the development of circular economy. By the proposed early-warning model, this paper analyzed the circular economy of Henan province. The development level of Henan's circular economy shows a better trend in the whole. Specifically, the warning degree of early warning system for Henan's circular economy are giant police in 2005 and 2006, heavy police in 2007, intermediate police in 2008 and 2009, and light police from 2010 to 2013. These mostly are due to Henan pays attention to circular economy, takes sustainable development road, and doesn't develop economy at the expense of environment, which is the important content of the viewpoint for the scientific development.

Based on the analysis of early warning system of Henan, early warning of the development of circular economy in Henan province over the next ten years will enter a police precinct, economic production mode will be in line with the principle of circular economy that is resource conservation, less pollution, high degree of resource reuse. But there still exist many problems, such as the efficiency of resource utilization is a little low, pollution is still in a high precinct, pollution control funds still need to add. If Henan does not adjust and control timely, it may exacerbate the earlywarning degree.

Henan province is the largest part of the central economic zone provinces, is also a big economic province and major agricultural province, is the leading provinces in the Midwest, but at the same time is also a big resourceconsumption province. Therefore, Rapid economic development is important, but from the point of view of sustainable development, simultaneously must ensure that the emissions shall not exceed the maximum environmental capacity. Resource utilization must be in a planned way, blindly predatory use of the resource must cause the alert degree of Henan's circular economy rise in the future.

\section{References}

1. Zhang B. Research and empirical evaluation of index system of circular economy. Chinese population, resources and environment, 2005 (3):22-25.

2. Yang HF. The construction of evaluation index system of circular economy. Management science and technology, 2005 (9) :123-128.

3. Ouyang LW. Research on index system of circular economy development. Environmental science and management, 2006 (6):117-120.

4. Zhao B. The design of evaluation index system of circular economy development. Economic system reform, 2007 (1):173-176. 
5. Xiang LS. Analysis of evaluation index system of circular economy. Chinese population, resources and environment, 2007 (2) : 76-78.

6. Zhong TY. Assessment of regional circular economy: method, index system and empirical research. resources science, 2006 (3) : 154-161.

7. Cao XL. Index system, Evaluation method and empirical study of regional circular economy. Journal of chongqing university (social science), 2008 (3) : 30-35.

8. Cao HP. Dynamic evaluation of regional circular economy development base on MFA with AHP, resources science, 2009, 31 (2) : 278-287.

9. Tong JP. Early warning system for regional circular economy. System engineering, 2008 (9) : 104-110.

10. Qin LB. The application of sustainability assessment of comprehensive ecological suitability in regional innovation system. Systems engineering theory and practice,2011(5):87-93.

11. Qian WY, Dang RG. The application of early warning model of development of circular economy system. System engineering theory and practice, 2013 (7) :56-63. 